\title{
A Year After the Fire: as the Phenix is Rising from Ash, The National Museum Lives
}

\author{
Mariane Pimentel Tutui*1 \\ Department of History, State University of Maringa, Brazil
}

Submission: September 09, 2019; Published: November 06, 2019

*Corresponding author: Mariane Pimentel Tutui, Department of History, State University of Maringa, Brazil

\begin{abstract}
This text consists of a brief essay that intends to discuss the trajectory of time that took place since the National Museum (UFRJ) fire until the current period. Located at Quinta da Boa Vista in Rio de Janeiro, Brazil, the National Museum suffered a fire in late 2018 that devastated much of its collection. A year after the event, scientists and students try to recover the collections, collecting items and resuming their studies. In addition to the rescue of pieces, the museum space also has donations that help to recompose the collection and the realization of exhibitions and side projects.

Keywords: National Museum; Brazil; Archeology
\end{abstract}

\section{Introduction}

This essay aims to guide your discussions about what has been done after the National Museum (UFRJ) fire. The National Museum is in the historic São Cristóvão Palace, in Quinta da Boa Vista, Rio de Janeiro. It is the oldest scientific institution and museum in Brazil, having completed its bicentenary in 2018. On September 2 of the same year, a huge fire engulfed the museum destroying thousands of years of national and world history ${ }^{2}$. In addition to the 40,000 indigenous artifacts, the fire also destroyed a rich 19th-century Amazonian ethnographic collection that was in the basements of the traditional institution. A year after that, a lot has been done to reclaim the space. The institution shows its resilience with the launching of exhibitions and other activities, as well as donations that help to restore the scientific collection, while the institution's main building is undergoing an arduous process of reconstruction (Figure 1). Since then, the museum has been surrounded by metal siding and the installation of a provisional ceiling (also made of metallic material) has been carried out. Containers were placed to function as warehouses and laboratories, and the old garage became a space for sorting objects [1-3].

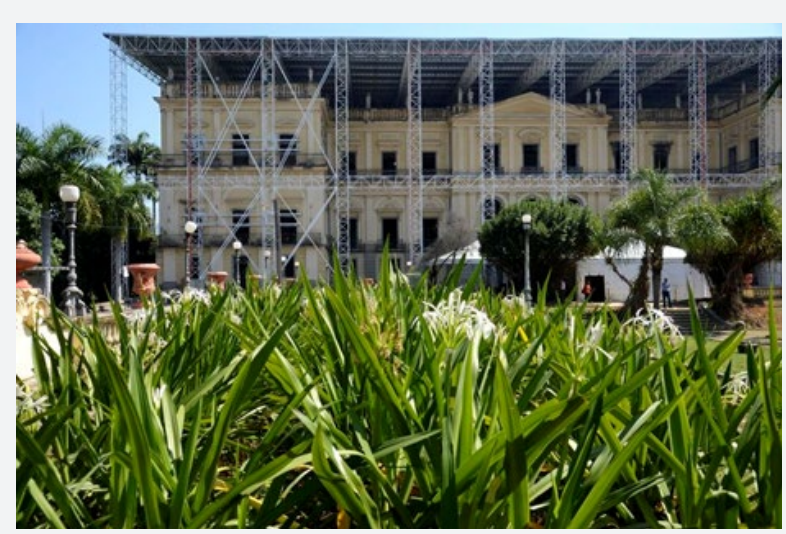

Figure 1: National Museum Reconstruction - Photo of Tania Rego / Agência Brasil.

${ }^{1}$ Graduated in History from the State University of Maringá - PR (2010) and master's in history in the research line: Borders, Populations and Cultural Goods from the same university (2014). Contact: +55 (15) 981285741 / marianetutui@hotmail.com / Address: 897 Narlir Miguel Street - Zip Code: 18230-000 Sao Miguel Arcanjo, Sao Paulo - Brazil.

${ }^{2}$ Archaeological, anthropological, geological and paleontological artifacts were destroyed, as well as hundreds of thousands of books and documents, audios and recordings of extinct indigenous languages. In addition to indigenous artifacts, there were Empire-era documents, fossils, mineral collections, Greco-Roman artifacts, and the largest Egyptian collection in Latin America. Among its most well-known items were the skeleton of the largest Brazilian carnivorous dinosaur and the oldest human fossil discovered in Brazil. 
Scientists and students ${ }^{3}$ try to recover the collections, currently the work consists of removing the material and cataloging what was rescued. Paleontologists and archaeologists use shovels and brushes to remove debris and fetch new parts. Curators responsible for the content of that area also help in the search. When a piece is found, it is photographed and proceeds to sorting in boxes. In sorting objects are cleaned and re-photographed and recorded; The fragile object is treated in the laboratory containers and, once stabilized and in good condition, is stored in the storage containers. When the searches are over, the objects found will be compared to the collection records and searches. At the end a report will be made of all that was found or lost. According to the museum's statements, this search phase should continue until the first half of 2020, where the inventory and report of the recovered material will be made later. So far important pieces of research have been recovered, such as human skeletons, including fragments of the skull of Luzia (the oldest fossil found on the American continent. Also rescued pieces from the Tereza Cristina Collection of preColumbian art from Peru, parts of the samurai armor from Japan and some items from the Egyptian collection, which has had over 300 pieces rescued ${ }^{4}$.

According to museum notes, more than 25 missing pieces have been reconstructed on 3D printers. Paleontologists, archaeologists, researchers and designers worked together on the project, which reproduced copies identical to those destroyed by the fire (each impression took more than 20 hours to complete) - among them the skull of Luzia, the statue of Darwin ${ }^{5}$. The pieces were printed in 3D, using the ashes found in the rubble, symbolically. The printing that also used charcoal and burnt wood common with the resin for 3D printer, was possible due to a collection of tomographs that the CDPI (Diagnostic Imaging Clinic) made of the works before the fire, for digital archiving purposes. According to archaeologists, this technological innovation opens possibilities for fossil recovery. Even after the fire, the National Museum was able to display some of its pieces in exhibitions held in other cultural venues. At the beginning of the year (from February to April), the exhibition "National Museum Lives- Rescue Archeology", the exhibition that celebrated the restart of the museum, was exhibited at the Banco do Brazil Cultural Center in Rio de Janeiro (CCBB). 100 works rescued from the fire.

The Mint, also in Rio de Janeiro, receives until September the exhibition "When Not Everything Was Ice - New Discoveries on the Antarctica". In the Cultural Box of Rio de Janeiro (from
September to December), the exhibition "Vila Santo Antônio de Sá: the first village of Guanabara's Recôncavo" is on display. The show brings together 11 items from the rubble and archaeological relics found by the institution's researchers in the area of Comperj (Rio de Janeiro State Petrochemical Complex), a metropolitan region of Rio de Janeiro. The pieces (crockery, objects and tools) reveal how the first inhabitants of the socalled Recôncavo da Guanabara (area from Itaboraí to Macacu Waterfall) lived. Also, in September, the exhibition "National Museum Live! Memories and Perspectives", at the National Congress, in Brasilia. The exhibition tells the history of the National Museum since its creation (1818) and the importance of the institution in the history of Brazil $[4,5]$.

From September 30 to October 4 in the auditorium of the Museum Central Library, located in the Botanical Garden, SEMNA (an activity promoted by the National Museum Graduate Program in Archeology - UFRJ) brings together researchers from the area of Egyptology in an enabling environment for debate and academic cooperation. The Francisca Keller Library of the Graduate Program in Social Anthropology, which had 37,000 documents and books and was fully incinerated, is already being rebuilt through donations and the crowdfunding campaign. Paleontologist and director of the National Museum, Alexandre Kellner, announced that the Brazilian Academy of Sciences (ABC) will release a book about the rescue work done at the National Museum. In addition, a documentary produced by the UFRJ media coordinator will be available online from September 19th. The documentary "Resgates" shows testimonials from technicians who worked in the Museum's emergency works, a sensitive, dedicated and emotionally charged production.

After a year of hardship, the National Museum shows its resilience. The goal of reopening a part of the palace with exhibitions is for 2022, according to information from the rectory of the Federal University of Rio de Janeiro (UFRJ).

\section{Final Considerations:}

The urban landscape and the artistic manifestations inserted in public areas provide the researcher with elements capable of arousing reflection on the representations of historical memories and identities created in the collective space. The recognition of a heritage implies the perceptions of social dynamics and the struggle for the preservation of our identity and memory. Our memory can be revived through remarkable sensations, smells, sounds, tastes and distinct forms of visual representations of the urban environment. Socially constructed memory appears

${ }^{3}$ In total, 47 museum staff actively participate in the rescue, as well as undergraduate and graduate students. Source: http://www.museunacional.ufrj. br. Access on 14 September. 2019.

${ }^{4}$ Source: http://agenciabrasil.ebc.com.br/educacao/noticia/2019-08/museu-nacional--do-rio-deve-reabrir-exposicao-no-palacio-em-2022. Access on 13 September. 2019

${ }^{5}$ An exhibition commemorating the 210th anniversary of Darwin's birth exhibits pieces from the National Museum. "Darwin Origens \& Evolução" runs from August 30th to October 30th at the Environmental Museum, located at the Rio de Janeiro Botanical Garden Research Institute. Among the species of the National Museum collection, the reptiles Jacaré-açú and the Gecko stand out. The latter being one of the species collected by Charles Darwin during his celebrated trip at the HMS Beagle at the stops in Salvador and Rio de Janeiro. Source: http://www.museunacional.ufrj.br. Access on 15 Sep. 2019. 
related to memories associated with monuments and places; The observation of the artistic manifestations placed in the public space can provide valuable clues regarding the ways of thinking history, both local, national and global. As historian Peter Burke points out: "In different countries, people have different ways of remembering the past ${ }^{6} .$. A historical archeology of the cities, including the contemporary ones, allows for distinct readings of the above question. The material culture and the social-political references impregnated in the historical monuments, the denominations of the space and the archaeological remains keep codes used by the social subjects to produce meaning aiming at meanings such as national identity and ethnic difference.

In the face of the catastrophe that occurred at the National Museum, a tragedy not only for Brazil but for the world, it is even more important to reinforce the discourse of struggle and safeguard before our collective memories. The museum's fire reflects the neglect of national heritage, science and technology; besides revealing to us the lack of policies to preserve the artistic, material and documentary heritage in Brazil. In the face of numerous challenges, the attitude of protecting local heritage and improving the preservation policies of collections should be encouraged in order to safeguard the plural roots of peoples and their cultural traditions as they express ethnic origins and imply conservation of their identities. There is the prospect of restoring the museum's historical building, the symbolic restoration of its collection and the reaffirmation of the institution's vocation to promote renewal, research and dissemination of knowledge as a form of social inclusion. As we have exposed, the National Museum remains alive and active and its memory is present in the collective unconscious, fueled for many decades by exhibitions aimed at the general public and focused on school visits from the public-school system. It should be added here that the caution of memory becomes an "urgency" as contemporary society seeks to preserve past traces that allow it to reorganize itself.

We must once again emphasize that respect for heritage and cultural diversity is imminent. We hope that the notes of this brief essay now presented can contribute in this direction and, perhaps, instigate new works on the subject.

\section{Electronic Addresses}

http://agenciabrasil.ebc.com.br/

http://www.museunacional.ufrj.br

http://www.revistahcsm.coc.fiocruz.br/

\section{References}

1. Araujo, Ana L (2019) The Death of Brazil's National Museum. The American Historical Review April pages EUA. 124(2): 569-580.

2. Burke, Peter (2005) The charming soul of the streets. Folha de S. Paulo, São Paulo, Notebook More p. 3.

3. Coli, Jorge (2006) How to study Brazilian art of the nineteenth century? Sao Paulo, Brazil: Publisher Senac p. 18.

4. Funari, Pedro PA, Robrahn-González E (2008) Ethics, capitalism and public archeology in Brazil. Story. Sao Paulo, Brazil 27(2): 13-30.

5. Tutui, Mariane P (2019) Debret and Public Archeology: The Tikuna Mask and the Fire of the National Museumain. Global Journal of Archeology \& Anthropology (GJAA) 9(2): 1-7.

\section{Your next submission with Juniper Publishers will reach you the below assets}

- Quality Editorial service

- Swift Peer Review

- Reprints availability

- E-prints Service

- Manuscript Podcast for convenient understanding

- Global attainment for your research

- Manuscript accessibility in different formats

( Pdf, E-pub, Full Text, Audio)

- Unceasing customer service

Track the below URL for one-step submission https://juniperpublishers.com/online-submission.php 